\begin{tabular}{|c|c|}
\hline SIL AMIMPA & $\begin{array}{l}\text { PRINTED ISSN: } 2620-6919 \\
\text { ONLINE ISSN: } 2620-3316\end{array}$ \\
\hline $\begin{array}{l}\text { Published by LP4MK STKIP PGRI LUBUKLINGGAU } \\
\text { Prodi Pendidikan Bahasa Indonesia, STKIP PGRI Lubuklinggau, } \\
\text { South Sumatera, Indonesia }\end{array}$ & $\begin{array}{r}\text { Vol. 1, No. 1, } 2018 \\
\text { Page: } 84-97\end{array}$ \\
\hline
\end{tabular}

\title{
INTERFERENSI MORFOLOGI DALAM KARANGAN NARASI MAHASISWA THAILAND SEMESTER IV PENDIDIKAN BAHASA DAN SASTRA INDONESIA FKIP UNIVERSITAS MUHAMMADIYAH TANGERANG
}

\author{
Mutoharoh ${ }^{1}$, Agus Sulaeman², \& Goziyah ${ }^{3}$ \\ 1,2,3Universitas Muhammadiyah Tangerang \\ JIn. Perintis Kemerdekaan I, No. 33 Cikokol, Tangerang, Indonesia \\ Email: mutoharoh567@gmail.com, sultanwahyu13@gmail.com, tiasagoziyah@yahoo.com
}

\begin{abstract}
Abstrak
Tujuan penelitian ini untuk mendeskripsikan bentuk-bentuk interferensi morfologi bahasa Melayu Thailand terhadap bahasa Indonesia dalam karangan narasi mahasiswa Thailand semester 4 yang menempuh pendidikan Strata 1 Program Studi Pendidikan Bahasa dan Sastra Indonesia, Fakultas Keguruan dan IImu Pendidikan, Universitas Muhammadiyah Tangerang. Untuk menemukan interferensi morfologi dalam karangan narasi, peneliti menggunakan metode deskriptif kualitatif, dan dianalisis dengan metode analisis isi. Teknik pengumpulan data menggunakan teknik dokumentasi berupa hasil karangan narasi tujuh mahasiswa Thailand, dari data yang diperoleh peneliti menganalisis bentuk-bentuk interferensi dari bentuk afiksasi, reduplikasi, dan pemajemukan dalam bahasa Indonesia. Teknik analisis data dengan langkah-langkah: teknik analisis isi dimulai dengan menentukan masalah penelitian, kategorisasi, interpretasi, dan kesimpulan. Berdasarkan hasil penelitian terdapat interferensi pada karangan narasi mahasiswa Thailand semester IV PBSI FKIP Universitas Muhammadiyah Tangerang. Di dalam karangan yang mahasiswa buat, terlihat mahasiswa masih menggunakan bahasa Melayu dalam berkomunikasi secara lisan maupun tulisan. Temuan penelitian ini, juga menunjukkan bahwa banyaknya kata yang terinterferensi pada bentuk afiksasi kategori prefiks, sufiks, kombinasi afiks, konfiks, reduplikasi, dan komposisis sedangkan pada afiks kategori infiks tidak terdapat interferensi. Bentuk yang sering terinterferensi adalah pada bentuk afikasisi kategori prefiks, konfiks, dan komposisi dari ke enam karangan mahasiswa.
\end{abstract}

Kata kunci: interferensi morfologi, karangan narasi, mahasiswa Thailand

\section{INTERFERENCE OF MORPHOLOGY IN THESE NARRATED THAI COLLEGE STUDENTS STUDYING AT STUDY PROGRAM IN EDUCATIONAL LANGUAGES \& INDONESIAN LITERATURE FKIP MUHAMMADIYAH TANGERANG UNIVERSITY}

\begin{abstract}
The objective of this research was to describe the forms of morphological interference of Thai Malay to Indonesian in the narrative of Thai students of the 4th semester who studied in Strata 1 Indonesian Language and Literature Education Study Program, Faculty of Teacher Training and Education, Muhammadiyah Tangerang University. To find morphological interference in narrative essay, the researcher uses qualitative descriptive method, and analyzed by content analysis method. Data collection techniques used documentation techniques in the form of a narrative of seven Thai students, from data obtained by researchers analyzing the forms of interference from
\end{abstract}


the form of affixation, reduplication, and compounding in the Indonesian language. Data analysis techniques with steps: content analysis techniques begin by determining research problems, categorization, interpretation, and conclusions. Based on the result of the research, there is interference on student narration of Thailand semester IV PBSI FKIP, Muhammadiyah Tangerang University. In the essay that the students make, it is seen that students still use Malay language in communicating orally and in writing. The findings of this study also show that the number of interferenced words in the form of affixation of categories of prefixes, suffixes, affix combinations, confix, reduplication and compositions whereas in the affix of the infix category there is no interference. Frequently interfered forms are in the form of affiliation categories of prefixes, confixes, and compositions of the six student compositions.

Keywords: morphological interference, narrative essay, Thai college students

\section{A. Pendahuluan}

Era globalisasi sekarang ini, banyak orang asing yang tertarik untuk menempuh pendidikan di Indonesia. Tidak sedikit juga banyak mahasiswa asing yang tertarik untuk kuliah di Indonesia dan mengambil jurusan Bahasa dan Budaya Indonesia, Fakultas Keguruan dan IImu Pendidikan yang tersedia di beberapa universitas yang berada di Indonesia. Salah satunya di Universitas Muhammadiyah Tangerang. Saat ini ada tujuh orang mahasiswa asing asal Selatan Thailand yang sedang menempuh pendidikan di Universitas Muhammadiyah Tangerang dan memilih Program Studi Pendidikan Bahasa dan Sastra Indonesia sebanyak enam orang.

Mayoritas, masyarakat Selatan Thailand berkomunikasi menggunakan bahasa Melayu dan Phasa Thai (bahasa resmi Thailand). Penguasaan bahasa Indonesia merupakan syarat bagi mahasiswa asing yang ingin kuliah di Indonesia karena bahasa Indonesia menjadi bahasa pengantar proses perkuliahan reguler di universitas yang ada di Indonesia, terutama Universitas Muhammadiyah Tangerang. Pembelajaran bahasa Indonesia untuk mahasiswa asing pasti tidaklah mudah untuk dipelajari, pasti ada saja kendala dalam mempelajarinya untuk mahasiswa asing seperti yang diketahui, mahasiswa asing yang berada di Universitas Muhammadiyah Tangerang menggunakan bahasa Melayu dalam bahasa kesehariannya di Selatan Thailand. Kedua hal ini dapat diketahui melalui perbandingan bahasa ibu dengan bahasa asing untuk mendapatkan persamaan dan perbedaan kedua bahasa tersebut dengan menganalisisnya secara kontrastif. Semakin besar perbedaan sistem bahasa ibu dengan suatu bahasa lain, maka 
semakin besar pula masalah yang dihadapi oleh seseorang dalam mempelajari bahasa tersebut karenanya semakin besar pula potensi terjadinya interferensi. Biasanya interferensi ini terjadi dalam menggunakan bahasa ke dua (B-2) dan yang berinterferensi ke dalam bahasa kedua itu adalah bahasa pertama atau bahasa ibu (Chaer dan Agustina, 2010).

Mahasiswa Thailand yang berada di Universitas Muhammadiyah Tangerang, selain bisa menggunakan bahasa Indonesia, mereka juga bisa berbahasa Melayu, bahasa Thailand, dan bahasa Inggris. Hal ini membuat para mahasiswa asing yang berada di Unversitas Muhammadiyah Tangerang menjadi dwibahasawan yang menguasai dua bahasa atau lebih. Interferensi mahasiswa asing Universitas Muhammadiyah Tangerang dapat terjadi pada penuturan lisan maupun tulisan. Interferensi yang terjadi dalam bahasa tulis tidak hanya dalam kesalahan pemilihan diksi, tetapi bisa juga terjadi pada kategori pemilihan ketepatan afiks, reduplikasi atau komposisi yang dapat diamati pada hasil karangan narasi yang ditulis oleh mahasiswa. Salah satu bentuk penyimpangan bahasa yang dapat diamati pada karangan mahasiswa asing yaitu interferensi morfologi. Misalnya pada struktur kalimat atau pemilihan kata dalam karangan narasi yang sudah mereka buat.

Interferensi harus ditangani sedini mungkin, terutama dalam dunia pendidikan. Interferensi merupakan pelanggaran berbahasa yang mengakibatkan rusaknya bahasa Indonesia. Cara mencegah penyebaran interferensi adalah dengan melakukan penelitian mengenai interferensi yang terjadi dalam dunia pendidikan dan memperbaikinya sedini mungkin. Menurut Brown (2008:109) interferensi merupakan transfer negatif yang terjadi ketika performa sebelumnya mengganggu performa pembelajaran sesudahnya, yang mana materi-materi yang dipelajari sebelumnya mencampuri materi-materi berikutnya. Sudah lumrah dalam pembelajaran bahasa kedua untuk menegaskan peran interferensi, yaitu efek-efek interferensi bahasa asli terhadap bahasa sasaran (B-2). Hal senada juga yang dikatakan Tarigan (2009:2) tentang teori belajar berdasarkan psikologi behavioris kebiasaan berbahasa kedua disebabkan oleh transfer negatif atau interferensi B-1 terhadap B-2. Artinya interferensi menyebabkan proses pembelajaran penutur B-1 
terhadap B-2 menjadi terganggu. Sedangkan Nurhadi (2010:50) menyatakan adanya tiga penyebab utama interferensi yaitu, (1) language transfer, yaitu kesalahan sebagai akibat adanya bahasa ibu (B1); (2) intralingual, yaitu kesalahan yang bukan berupa interferensi, melainkan sebagai akibat dari proses belajar itu sendiri (kekhilafan perkembangan); dan (3) teaching techniques or materials (process hypothesing flaseconcepts) yaitu interferensi akibat kesalahan teknik mengajar atau materi.

Chaer (2008:120) menjelaskan bahwa untuk menyebut adanya perubahan sistem suatu bahasa sehubungan dengan adanya persentuhan bahasa tersebut perlu dikaitkan dengan unsur-unsur bahasa lain yang dilakukan oleh penutur yang bilingual. Penutur yang bilingual adalah penutur yang menggunakan dua bahasa secara bergantian dan penutur multilingual, kalau ada, tentu penutur yang dapat menggunakan banyak bahasa secara bergantian. Namun, penutur B-1 dan B-2 sangat bervariasi. Ada penutur yang menguasai B-1 dan B-2 sama baiknya, tetapi ada pula yang tidak, malah ada yang kemampuanya terhadap B-2 sangat minim.

Penutur bilingual yang mempunyai kemampuan terhadap B-1dan B-2 sama baiknya, tentu tidak mempunyai kesulitan untuk menggunakan kedua bahasa itu kapan saja diperlukan, karena tindak berlaku kedua bahasa itu terpisah dan bekerja sendiri-sendiri. Penutur bilingual yang mempunyai kemampuan menurut Chaer (2008:121) disebut kemampuan bahasa yang sejajar. Sedangkan kemampuan terhadap B-2 jauh lebih rendah atau tidak sama dari kemampuan B1nya disebut kemampuan bahasa yang majemuk. Penutur yang mempunyai kemampuan majemuk ini biasanya mempunyai kesulitan dalam menggunakan B2nya karena akan dipengaruhi oleh kemampuan B1-nya.

Khusus untuk interferensi morfologi dipandang para ahli bahasa sebagai interferensi yang paling banyak terjadi. Interferensi in iterjadi dalam pembentukan kata dengan penyerapan kata dan afiks-afiks bahasa lain. Menurut Ramlan (2009:21) dengan ringkas mengatakan bahwa morfologi ialah bagian dari ilmu bahasa yang membicarakan atau yang mempelajari seluk-beluk bentuk kata serta pengaruh perubahan-perubahan bentuk kata terhadap golongan dan arti kata, atau dengan kata lain dikatakan bahwa morfologi mempelajari seluk-beluk bentuk Silampari Bisa: Jurnal Penelitian Pendidikan Bahasa Indonesia, Daerah, dan Asing Vol. 1, No. 1, 2018 
kata serta fungsi perubahan-perubahan bentuk kata itu, baik fungsi gramatik maupun semantik.

Menurut Chaer (2008:3) dalam kajian linguistik, mofologi berarti ilmu mengenai bentuk-bentuk dan pembentukan kata. Sedangkan Alwasilah (2010:110) morfologi adalah bagian linguistik yang mempelajari morfem. Morfologi mempelajari dan menganalisis struktur, bentuk, dan klasifikasi kata-kata. IImu morfologi menyangkut struktur internal kata. Kata seperti tertidur. Kata ini terdiri atas dua "morfem", yakni ter- dan tidur (ter- diberi garis karena tidak pernah berdiri sendiri). Jadi kata tertidur mempunyai struktur "internal" dengan bagianbagiannya ter- dan tidur. Kata tidur itu sendiri terdiri atas satu morfem saja, yaitu tidur.

Interferensi yang sering terjadi juga pada sebuah tulisan narasi. Istilah narasi (berasal dari narration $=$ bercerita). Kosasih (2003:26) mengatakan karangan narasi adalah karangan yang menceritakan suatu peristiwa atau kejadian dengan tujuan agar pembaca seolah-olah mengalami kejadian yang diceritakan itu. Hal senada juga dikatakan Lamuddin (2010:244), karangan narasi adalah suatu bentuk tulisan yang berusaha menciptakan, mengisahkan, dan merangkaikan tindak-tanduk perbuatan manusia dalam sebuah peristiwa secara kronologis atau yang berlangsung dalam suatu kesatuan waktu.

Dari segi sifatnya karangan narasi dibedakan atas dua macam pertama narasi ekspositoris/narasi faktual, narasi yang hanya bertujuan untuk memberi informasi kepada pembaca agar pengetahuannya bertambah luas. Kedua narasi sugestif/narasi berplot, narasi yang mampu menyampaikan makna kepada pembaca melalui daya khayal. Setiap narasi memiliki sebuah plot atau alur yang didasarkan pada kesinambungan peristiwa-peristiwa dalam narasi itu dalam hubungan sebab-akibat. Ada bagian yang mengawali narasi itu, ada bagian yang merupakan perkembangan lebih lanjut dari situasi awal, dan ada bagian yang mengakhiri narasi itu. Alurlah yang menandai kapan sebuah narasi itu dan kapan mulai berakhir.

Suparno \& Yunus (2008:4.31) mengatakan istiah narasi atau sering juga disebut naratif berasal dari kata bahasa Inggris narration (cerita) dan narrative 
(yang menceritakan). Karangan yang disebut narasi menyajikan serangakaian peristiwa. Karangan ini berusaha menyampaikan serangkian kejadian menurut urutan terjadinya (kronologis), dengan maksud memberi arti kepada sebuah atau serentetan kejadian, sehingga pembaca dapat memetik hikmah dari cerita itu.

Hasil penelitian relevan dengan penelitian ini yaitu penelitian yang dilaksanakan oleh Suindratini dkk. (2013) berjudul Interferensi Bahasa Bali dan Bahasa Asing dalam Cerita Lisan Bahasa Indonesia Kelas VII Siswa SMP Negeri 10 Denpasar. Hasil penelitian ini menunjukkan bahwa dalam interferensi bahasa Bali terdapat jenis interferensi fonologi, morfologi, sintaksis, semantik, sedangkan dalam interferensi bahasa asing terdapat interferensi sintaksis dan semantik. Terjadinya interferensi bahasa Bali ke dalam bahasa Indonesia memperlihatkan bahwa interferensi terjadi bukan disengaja oleh siswa dengan maksud untuk mempermudah penyampaian buah pikirannya, tetapi terjadi karena penguasaan sistem bahasa pertama (bahasa Bali) mereka yang lebih tinggi dari kemampuan mereka bertutur dengan bahasa Indonesia. Dari penelitian relevan ini, semua aspek interferensi diteliti sedangkan dalam penelitian ini difokuskan pada interferensi pada karangan narasi mahasiswa Thailand yang belajar di Indonesia yaitu di Universitas Muhammadiyah Tangerang.

Penelitian relevan berikutnya yaitu dilaksanakan oleh Hadi (2010) dengan judul Interferensi Sintaksis Bahasa Indonesia terhadap Bahasa Jerman Dalam Karangan Mahasiswa Jurusan Sastra Jerman Pada Matajuliah Aufsatz I. Hasil penelitian menunjukkan bahwa: (1) bentuk interferensi pada urutan kata ditandai dengan terdapat kesalahan posisi kata kerja; (2) bentuk interferensi penanggalan unsur kalimat, ditandai dengan tidak hadirnya subjek, predikat, objek, artikel, konjungsi, preposisi dan kata ganti refleksif, serta tidak adanya konjugasi terhadap kata kerja; (3) bentuk interferensi berupa penambahan dan penggunaan unsur kalimat. Bentuk interferensi penambahan unsur kalimat ditandai dengan hadirnya predikat, objek, kata ganti, dan preposisi yang tidak fungsional berdasarkan kaidah sintaksis bahasa Jerman. Kemudian, bentuk interferensi penggunaan pada unsur kalimat ditandai dengan penggunaan subjek, predikat, adverbia, artikel, dan komposita yang tidak sesuai konteks kalimat berdasarkan kaidah sintaksis bahasa 
Jerman. Bentuk-bentuk interferensi sintaksis tersebut terjadi karena kurangnya penguasaan mahasiswa terhadap kaidah sintaksis bahasa Jerman. Akibatnya, mereka cenderung menyusun sebuah kalimat yang mengandung interferensi sintaksis tanpa menganalisis terlebih dahulu bentuk gramatikal kalimat yang akan disusun. Dalam penelitian relevan ini meneliti bagian interferensi sintaksis sedangkan dalam penelitian ini difokuskan pada interferensi morfologi pada karangan narasi mahasiswa Thailand yang belajar di Universitas Muhammadiyah Tangerang.

Penelitian tentang interferensi juga sudah dilaksanakan oleh Artana (2015) dengan judul Interferensi Pemahaman Struktur Kalimat Bahasa Indonesia oleh Mahasiswa Jepang dalam Pembelajaran Bahasa Indonesia. Hasil penelitian menunjukkan bahwa bahwa mahasiswa Jepang sulit memahami struktur kalimat karena: 1) penguasaan kosakata $\mathrm{BI}$, baik dari segi fungsi maupun dari segi makna masih kurang; dan 2) Satuan-satuan linguistik sebagai unsur pembentuk struktur kalimat belum dikuasai; 3) Penguasaan struktur kalimat bahasa ibu masih melekat sehingga terjadi interferensi ke dalam BI sebagai bahasa asing; 4) terdapat perbedaan yang mencolok antara struktur pola kalimat BI sebagai bahasa asing (bahasa kedua) dengan bahasa ibu dalam bahasa Jepang (bahasa pertama); dan 5) mahasiswa Jepang masih menggunakan B1 pada saat menggunakan B2 atau transfer (pembelajaran) negatif. Dari hasil penelitian ini berbeda dengan penelitian yang peneliti lakukan yaitu meneliti interferensi morfologi dalam karangan narasi mahasiswa Thailand sedangkan dalam penelitian ini interferensi struktur kalimat bahasa Indonesia oleh mahasiswa Jepang.

Dalam penelitian ini, peneliti akan mencoba membuktikan apakah masih terdapat kesalahan atau interferensi morfologi dalam sebuah tulisan narasi dan dan bagaimana perkembangan Bahasa mahasiswa asing yang belajar di Indonesia khususnya di Universitas Muhammadiyah Tangerang dalam menguasai Bahasa kedua yaitu bahasa Indonesia. Untuk itu, pentingnya dilakukan penelitian tentang bentuk-bentuk interferensi morfologi bahasa Melayu Thailand terhadap bahasa Indonesia dalam karangan narasi mahasiswa Thailand semester 4 yang menempuh pendidikan Strata-1 Program Studi Pendidikan Bahasa dan Sastra 
Indonesia, Fakultas Keguruan dan IImu Pendidikan, Universitas Muhammadiyah Tangerang. Dengan harapan, hasil penelitian ini dapat dijadikan masukan dalam pengembangan pembelajaran bahasa kedua di Indonesia dan solusi dalam mengatasi pembelajar bahasa kedua yang mengalami interferensi. Selain itu, penelitian ini juga bermanfaat dalam mencegah kesalahan yang berkelanjutan bagi penutur bahasa Indonesia.

\section{B. Metode Penelitian}

Penelitian ini, termasuk penelitian kualitatif karena datanya berupa data kualitatif, yaitu kata bahasa Indonesia yang salah yang digunakan oleh Mahasiswa Thailand Semester IV PBSI FKIP Universitas Muhammadiyah Tangerang. Sumber data yang diamati pada penelitian ini adalah tulisan tangan bahasa Indonesia mahasiswa Thailand yang berbahasa ibu bahasa Melayu. Hasil analisis data dipaparkan dalam bentuk deskripsi dan bukan data numerikal sehingga pada penelitian ini termasuk jenis penelitian deskripsi analaisis teks. Teknik pengumpulan data menggunakan teknik observasi dan studi dokumen.

Teknik analisis data yang digunakan dalam penelitian ini menggunakan teknik analisis isi. Data yang dianalisi berjumlah enam karangan. Data tesebut diambil dari 6 orang mahasiswa Thailand yang sedang menempuh pendidikan di Universitas Muhammadiyah Tangerang. Data hasil karangan deskripsi dianalisis dengan cara melihat dan mengelompokkan bentuk-bentuk interferensi morfologi yang ditampilkan. Kemudian, pengelompokan interferensi morfologi dibagi berdasarkan interferensi bentuk afiksasi prefiks, sufiks, infiks, kombinasi afiks, dan konfiks), reduplikasi, dan komposisi. Cara mengetahui bentuk-bentuk interferensi morfologi, yaitu dengan cara membuat tabulasi data interferensi morfologis, karena untuk mempermudah menganalisis karangan deskripsi mahasiswa Thailand, maka dari setiap karangan yang telah dianalisis langsung dikelompokkan dalam tabulasi data dalam bentuk interferensi. 


\section{Hasil Penelitian dan Pembahasan}

\section{Hasil Penelitian}

Berikut ini merupakan data hasil penelitian bentuk interferensi morfologis dialek bahasa Melayu Thailand dalam bahasa Indonesia pada karangan mahasiswa semester 4 Program Studi Pendidikan Bahasa dan Sastra Indonesia (PBSI), FKIP, Universitas Muhammadiyah Tangerang dalam bentuk tabel berikut.

Tabel 1. Bentuk Interferensi Proses Pembubuhan Afiksasi Dalam Karangan Narasi Mahasiswa Thailand

\begin{tabular}{|c|c|}
\hline Jenis Teks & Kalimat yang Mengalami Interferensi Morfologi \\
\hline $\begin{array}{c}\text { Narasi } \\
(\text { Bagian 1) }\end{array}$ & $\begin{array}{l}\text { a. Disaat saya maik ankot warna biru. } \\
\text { b. Disaat saya maik ankot warna biru. } \\
\text { c. Disaat saya maik ankot warna biru. } \\
\text { d. Menuju kampus dan disaat diperjalanan. } \\
\text { e. Melihat berbagai macam diperjalanan salah satu motor, model, } \\
\quad \text { speda dan lain2nya. } \\
\text { f. Melihat berbagai macam diperjalanan salah satu motor, model, } \\
\text { speda dan lain2nya. } \\
\text { g. Dan disaat saya di angkot. } \\
\text { h. Setelah itu saya turung ankot menyeberang menuju kampus. } \\
\text { i. Setelah itu saya turung ankot menyeberang menuju kampus. }\end{array}$ \\
\hline $\begin{array}{c}\text { Narasi } \\
\text { Bagian } 2\end{array}$ & $\begin{array}{l}\text { a. Peta kali saya dan teman-teman saya disuruh ketemu sama kepala } \\
\text { sekolah. } \\
\text { b. Peta kali saya dan teman-teman saya disuruh ketemu sama kepala } \\
\text { sekolah. } \\
\text { c. guru pamong saya bernama bapa Abdulbasit. } \\
\text { d. Dan hari itu saya disuruh masuk kekalas } 10 \quad \text { IP untuk } \\
\text { mengobversihan. } \\
\text { e. Dan hari itu saya disuruh masuk kekalas } 10 \quad \text { IP untuk } \\
\text { mengobversihan. } \\
\text { f. Dan hari itu saya disuruh masuk kekalas } 10 \quad \text { IP untuk } \\
\text { mengobversihan. } \\
\text { g. saya disuruh bubuk disebuah kursi yang kosong untuk menyemati } \\
\text { aktivitas kelas pada hari itu. } \\
\text { h. saya disuruh bubuk disebuah kursi yang kosong untuk menyemati } \\
\text { aktivitas kelas pada hari itu. } \\
\text { i. Dan dua-dua kelas yang saya melihat sangat kompak sekali. } \\
\text { j. Mereka saling mengharigai guru dan saya. } \\
\text { k. Selam dua minggu. } \\
\text { l. Dan magang juga membuat saya bikin stress, pusing, cape. } \\
\text { m. Dan disitu membuat tahu perbedaan mahasiswa. } \\
\text { n. Disitu juga saya digodain sama anak murik disekolah. } \\
\text { o. Disitu juga saya digodain sama anak murik disekolah. } \\
\text { p. Di hari itu saya merana malu sekali. } \\
\text { q. Setelah itu ke kamar mandi mencerminkan. } \\
\text { r. Dan saya langsung keruangan tersebut ketemu sama temah saya. }\end{array}$ \\
\hline
\end{tabular}

Silampari Bisa: Jurnal Penelitian Pendidikan Bahasa Indonesia, Daerah, dan Asing Vol. 1, No. 1, 2018 
s. Dan saya langsung keruangan tersebut ketemu sama temah saya.

t. Hari pertama saya langsung nyampa.

u. Dan sampai hari ini merasakan nyesal sekali.

v. Dan sampai hari ini merasakan nyesal sekali.

Dari tabel di atas, dapat dijelaskan bahwa terdapat interferensi pada setiap karangan yang dibuat oleh mahasiswa Thailand. Interferensi tersebut dalam bentuk interferensi morfologi pada karangan narasi. Interferensi pada karangan narasi mahasiswa Thailand semester IV PBSI FKIP Universitas Muhammadiyah Tangerang. Di dalam karangan yang mahasiswa buat, terlihat mahasiswa masih menggunakan bahasa Melayu dalam berkomunikasi secara lisan maupun tulisan. Temuan penelitian ini, juga menunjukkan bahwa banyaknya kata yang terinterferensi pada bentuk afiksasi kategori prefiks, sufiks, kombinasi afiks, konfiks, reduplikasi, dan komposisis sedangkan pada afiks kategori infiks tidak terdapat interferensi. Bentuk yang sering terinterferensi adalah pada bentuk afikasisi kategori prefiks, konfiks, dan komposisi dari ke enam karangan narasi mahasiswa.

\section{Pembahasan}

Interferensi morfologi dalam karangan narasi mahasiswa Thailand yang belajar pada Program Studi Pendidikan Bahasa dan Sastra Indonesia, Universitas Muhammadiyah Tangerang dikarenakan proses pembubuhan afiks yang dijelaskan oleh Muslich (2008:38) bahwa proses pembubuhan afiks merupakan peristiwa pembentukan kata dengan jalan membubuhkan afiks pada bentuk dasar. Berdasarkan temuan data yang terkumpul, terdapat interferensi morfologis proses pembubuhan 19 bentuk macam kata dalam karangan narasi yang dibuat oleh mahasiswa Thailand. Pada teks yang mereka buat terdapat interferensi morfologis proses pembubuhan bahasa Melayu Thailand dalam bahasa Indonesia. Sebagai contoh data responden 1 (Yukiflee Bakalee). Teks narasi Yukiflee memilki kesalahan pembubuhan afiksasi sebanyak 9 kata, yaitu: Kalimat " $D i$ saat saya maik ankot warna biru." Pada teks narasi Yukiflee memiliki tiga kesalahan proses pembubuhan (afiksasi), yaitu pada kata maik yang seharusnya terdapat awalan 
(prefiks) me- dan akhiran (sufiks) -i. Perbaikan kata maik dalam bahasa Indonesia yang benar adalah menaiki. Kata angkot memiliki kesalahan proses pembubuhan yaitu pada sisipannya (infiks). Kata angkot dalam bahasa Indonesia yang benar adalah angkot. Kata warna juga memiliki kesalahan afiksasi, yaitu kata ini seharusnya memiliki awalan (prefiks) -ber. Perbaikan kata warna yang benar adalah berwarna. Jadi pada kalimat Disaat saya maik ankot warna biru yang benar adalah Di saat saya menaiki angkot berwarna biru.

Kalimat menuju kampus dan di saat diperjalanan pada teks narasi Yukiflee memiliki satu kesalahan pembubuhan afiksasi pada kata disaat, karena seharusnya tidak ada penambahan awalan (afiksasi) di-. Jadi, kalimat yang benar adalah menuju kampus dan saat diperjalanan. Kalimat "Melihat berbagai macam diperjalanan salah satu motor, model, speda dan lain2nya." terdapat dua kesalahan pembubuhan yaitu pada kata satu dan speda. Kata satu seharusnya memiliki akhiran (sufiks) -nya. Sedangkan kata speda terdapat kesalahan pada sisipan (infiks) yang seharusnya terdapat huruf -e setelah huruf $s$ - dan sebelum huruf -p-. Jadi kalimat yang benar adalah "Melihat berbagai macam di perjalanan salah satunya motor, model, sepeda, dan lain-lainnya."

Kalimat "Dan disaat saya di angkot." memiliki satu kesalahan pembubuhan pada kata disaat karena kata itu menimbulkan ketidakefektifan kalimat. Seharusnya pembubuhan -di dihilangkan. Jadi, bahasa Indonesia yang benar pada kalimat tersebut adalah dan saat saya di angkot. Kalimat "Setelah itu saya turung ankot menyeberang menuju kampus." terdapat dua kesalahan pembubuhan pada kata turung dan ankot. Kata turung pada kalimat tersebut memiliki kesalahan akhiran (sufiks) - $g$, seharusnya adalah turun. Kata ankot juga memiliki kesalahan imbuhan infiks, seharusnya angkot. Jadi, kalimat yang benar menurut bahasa Indonesia adalah "Setelah itu saya turun angkot menyeberang menuju kampus."

Kemudian, dari hasil penelitian ini dapat kita jelaskan bahwa interferensi morfologi dalam karangan narasi mahasiswa Thailand yaitu: 1) penggantian formasi pada fonem vokal /a/ dengan fonem /o/ dan konsonan /g/ menjadi / $/$. Contoh pada kata [mata] dalam bahasa Indonesia menggunakan huruf vokal /a/ 
pada akhir kata, tetapi mahasiswa menuliskannya menajdi [mato] diganti huruf vokal /a/ menjadi /o/ pada suku kata akhir, dan pada kata [kebun] dalam bahasa Indonesia menggunakan huruf konsonan /k/ pada awal kata mahasiswa menggantikannya menjadi [gebun] diganti huruf konsosnan /k/ menjadi /g/ pada diawal kata. 2) Penghilangan fonem vokal /a/ di tengah kata. Contoh pada kata [berusaha] dalam bahasa Indonesia mempunyai fonem /a/ di tengah kata, tetapi mahasiswa menuliskannya menjadi [berusha] berupa penghilangan fonem /a/ di tengah kata, dan pada kata [pertama] dalam bahasa Indonesia terdapat fomen konsonan dan vokal pada akhir kata tetapi mahasiswa menuliskannya menjadi [perta] berupa penghilangan fonem konsonan dan vokal pada akhir kata. 3) Penambahan afiks kategori kombinasi afiks. Contoh pada kata [memperbaiki] dalam bahasa indonesia kata dasar ditambahkan imbuhan memper-,,,-i, tetapi mahasiswa menggantinya menjadi [memperdibaiki] menambahkan kembali imbuhan -di ditengah kata dasar. Terakhir, 4) ketidaktepatan pemilihan imbuhan dengan kata dasar. Contoh pada kata [perumahan] dalam bahasa Indonesia kata dasar diberikan awalan pe- dan akhiran -an, tetapi mahasiswa menggantinya menjadi [kerumahan]. Dalam hal ini terjadi ketidaktepatan pemberian imbuhan pada awalan dan akhiran pada kata dasar.

\section{Simpulan}

Berdasarkan hasil penelitian dan pembahasan terdapat interferensi pada karangan narasi mahasiswa Thailand semester IV PBSI FKIP Universitas Muhammadiyah Tangerang. Di dalam karangan yang mahasiswa buat, terlihat mahasiswa masih menggunakan bahasa Melayu dalam berkomunikasi secara lisan maupun tulisan. Temuan penelitian ini, juga menunjukkan bahwa banyaknya kata yang terinterferensi pada bentuk afiksasi kategori prefiks, sufiks, kombinasi afiks, konfiks, reduplikasi, dan komposisis sedangkan pada afiks kategori infiks tidak terdapat interferensi. Bentuk yang sering terinterferensi adalah pada bentuk afikasisi kategori prefiks, konfiks, dan komposisi dari ke enam karangan mahasiswa. Beberapa interferensi dikarenakan beberapa hal, yaitu: 1) penggantian formasi pada fonem vokal /a/ dengan fonem /o/ dan konsonan /g/ 
menjadi /k/; 2) penghilangan fonem vokal /a/ di tengah kata; 3) penambahan afiks kategori kombinasi afiks; dan 4) ketidaktepatan pemilihan imbuhan dengan kata dasar.

Penelitian ini diharapkan dapat memberikan sumbangan dalam kajian bahasa yang berkaitan dengan pembelajaran bahasa khususnya bidang Morfologi dan Sosiolonguistik. Hasil penelitian ini diharapkan juga dapat digunakan sebagai pengetahuan bagi para calon guru Bahasa dan Sastra Indonesia yang ada di Universitas Muhammadiyah Tangerang.

\section{Daftar Pustaka}

Alwasilah, K. (2010). Linguistik Suatu Pengantar. Bandung: Angkasa.

Artana, I Nyoman Rauh. (2015). Interferensi Pemahaman Struktur Kalimat Bahasa Indonesia oleh Mahasiswa Jepang dalam Pembelajaran Bahasa Indonesia. Skripsi, Program Studi Sastra Jepang Fakultas Ilmu Budaya Universitas Udayana Denpasar. Diakses 6 November 2017. http://erepo.unud.ac.id/5000/1/bd93d7513fdc52b14e9c9628f13568e9.pdf

Brown, H. D. (2008). Prinsip Pembelajaran dan Pengajaran Bahasa. Kedubes USA: Pearson Education. Inc.

Chaer, Abdul dan Agustina, Leonie. (2010). Sosiolinguistik Perkenalan Awal. Jakarta: Rineka Cipta.

Chaer, Abdul. (2008). Morfologi Bahasa Indonesia. Jakarta: Rineka Cipta.

Hadi, Abdul. (2010). Interferensi Sintaksis Bahasa Indonesia terhadap Bahasa Jerman dalam Karangan Mahasiswa Jurusan Sastra Jerman pada Mata Kuliah Aufsatz I. Diakses pada 5 November 2017. http://karyailmiah.um.ac.id/index.php/sastra-jerman/article/view/7050

Kosasih, E. (2003). Kompetensi Ketatabahasaan dan Kesusastraan. Bandung: Yrama Widya.

Lamuddin, Finoza. (2010). Komposisi Bahasa Indonesia. Jakarta: Universitas Terbuka.

Muslich, Masnur. (2008). Tata Bentuk Bahasa Indonesia. Jakarta: PT Bumi Aksara. 
Nurhadi, Rokhan. (2010). Dimensi-Dimensi dalam Belajar Bahasa Kedua. Bandung: Sinar Baru.

Ramlan. (2009). Morfologi Suatu Tinjauan Deskriptif. Yogyakarta: CV. Karyono.

Suindratini, Dewa Ayu Nyoman dkk. (2013). Interferensi Bahasa Bali dan Bahasa Asing dalam Cerita Lisan Bahasa Indonesia Kelas VII Siswa SMP Negeri 10 Denpasar. E-Journal Program Pascasarjana Universitas Pendidikan Ganesha, Vol. 2. https://media.neliti.com/media/publications/206938interferensi-bahasa-bali-dan-bahasa-asin.pdf

Suparno dan Yunus, Mohamad. (2008). Keterampilan Menulis. Jakarta: Universitas Terbuka.

Tarigan, Henry Guntur. (2009). Pengajaran Analisis Kesalahan Berbahasa. Bandung: Angkasa. 